Miscellanea Anthropologica et Sociologica 2019, 20(1): 115-132

Michael Gubser ${ }^{1}$

\title{
Phenomenology contra Nazism: Dietrich von Hildebrand and Aurel Kolnai
}

This paper discusses the relationship between phenomenology and political activism in the work of two lesser-known second-generation phenomenologists: Dietrich von Hildebrand and Aurel Kolnai. As young philosophers in the 1920s, Hildebrand and Kolnai became staunch adherents of the phenomenological movement. Influenced especially by Max Scheler and Adolf Reinach, they were particularly interested in questions of ethical theory and moral action. In the 1930s, with the rise of Hitler, they joined an important circle of conservative Catholic critics of Nazism based around the journal Der christliche Ständestaat in Vienna. After examining the links between phenomenology and activism in their work, my essay concludes by considering how these two thinkers can revise our understanding of phenomenology's history of social engagement and its potential relevance to social and political debate today.

Key words: phenomenology, ethics, politics, Hildebrand, Kolnai, Nazism, Scheler

Beyond the circle of phenomenological scholars, the political implications of phenomenology are typically understood in two ways: either as non-existent or as bad. In the first sense, phenomenology is often considered an apolitical school of philosophy, concerned more with matters of logic, consciousness, and perception than with social and ethical theory. Robert Sokolowski's remark that "phenomenology has not developed a political philosophy" may be taken as emblematic and can be read by those outside the movement as suggesting political indifference. ${ }^{2}$ In the second sense, when phenomenologists do take political stands, they are usually considered quite poor. Heidegger is the obvious example here; the recent publication of his Schwarze Hefte from the late 1930s has reignited the longstanding

1 James Madison University, History Department, Harrisonburg (VA) (USA); gubsermd@jmu.edu.

2 Sokolowski 1999: 203-204. There are important exceptions: See, for example, Hart 1992; and, very recently, the essays collected in Szanto \& Moran 2016. 
debate about his Nazi allegiances. ${ }^{3}$ Sartre's Stalinism is another example the dubious political commitments emanating from wider phenomenological circles. ${ }^{4}$ One might also cite the strident German nationalism and war boosterism of Edmund Husserl and Max Scheler in World War I as further examples of the ill-conceived partnership of phenomenology and politics (Husserl 1987; Scheler 1982). These two characterizations - politically indifferent and politically appalling - can also be linked: phenomenological indifference to social philosophy means that it has no critical resources for making sound political decisions when they are needed. ${ }^{5}$ My essay challenges this characterization by highlighting two lesser known interwar philosophers - Dietrich von Hildebrand and Aurel Kolnai - who expanded phenomenology in the direction of social and ethical thought and then drew on it to mount a journalistic assault on National Socialism.

\section{Dietrich von Hildebrand}

Phenomenological interest in ethical and social themes coincided with the birth of movement itself. Franz Brentano and Edmund Husserl, for example, dedicated treatises to questions of moral awareness, empathy for the other, even sociopolitical arrangements. ${ }^{6}$ Outside of the war writings of Max Scheler and Husserl, however, this interest remained largely academic, accompanied by largely impotent hand-wringing about modern despair. Even Scheler, who more than anyone else established phenomenology as a social philosophy, is much better known for his assertion of the real existence of values and his analyses of the experience of sympathy than for his screeds against modern capitalism (Scheler 1972, 1973, 2008). When it came to practical concerns like choosing values or acting morally in a world of ethical disharmony - not to mention political action - early phenomenology came up short of immediate guidance; it was, in other words, better at describing moral circumstances than at prescribing appropriate stands. Dietrich von Hildebrand (1889-1977) was the first to mobilize it fully in the service of

3 For the most prominent English-language Heidegger prosecution, see Wolin 1992. The most recent attack - and the most radical in its effort to dismiss Heidegger's philosophy as Nazi ideology is Faye 2009. For a stringent critique of Faye and of the prosecutorial approach to intellectual history, see Gordon's review in Notre Dame Philosophical Reviews (Gordon 2010).

4 The classic criticism here is Judt 2011.

5 This picture is brightened when we consider East European phenomenologists such as Jan Patočka, Václav Havel, and Karol Wojtyla, who drew on phenomenology as fuel for anti-regime activism. On this story, see Gubser 2014; Tucker 2000; and Findlay 2002.

6 Brentano 1969, 1973; Husserl's well-known Cartesian Meditations (Husserl 1977) was delivered as a lecture in 1929, but its concern for ethics and otherness was anticipated by numerous manuscripts and articles over the preceding decade, notably the Kaizo essays on renewal from 1923, reprinted in Husserl 1973. 
activism. The son of a famous sculptor, Hildebrand is best-known as an interwar personalist who took up cudgels against National Socialism. Less familiar was his membership in the early phenomenological movement - and the influence of phenomenology on both his personalism and his anti-fascism. ${ }^{7}$

Hildebrand learned of phenomenology at the University of Munich, where he met Theodor Lipps, Alexander Pfänder, Moritz Geiger, Max Scheler, and Adolf Reinach - the latter particularly influential as a friend and teacher. ${ }^{8}$ As a young philosopher, he praised Husserl's seminal philosophy, though Scheler and Reinach, with their worldly concerns and rejection of transcendentalism, proved more direct phenomenological forebears. ${ }^{9}$ His first adumbration of an act-oriented moral theory came in a 1912 dissertation on ethical action, lauded by Husserl and later published in his house journal, the Jahrbuch für Philosophie und phänomenologische Forschung. ${ }^{10}$ The treatise offered a three-part anatomy of ethical acts: The first was conscious engagement with or taking notice of [Kenntnisnahme] a particular object or state of affairs. From this initial notice, a person took a position [Stellungnahme] regarding the object or situation based on an emotional reaction to the value with which it was laden. ${ }^{11}$ As Hildebrand explained in 1933, "[t]he soul of every morally good attitude is abandonment to that which is objectively important, is interest in a thing because it has value" (Hildenbrand 1950: 3). This value response [Wertantwort] was Hildebrand's signature addition to phenomenological ethics. ${ }^{12}$ Each value had its own proper emotional response, which in turn stirred action - the third element - aimed at realizing the value in a new and better state of affairs. ${ }^{13}$

Several points bear note. First, while Hildebrand indicated, like Scheler, that values attach to objects, ethics applied properly only to states of affairs [Sachverhalte] - situations relating persons to objects and values, such as an action designed to realize good in the world or a stance regarding a particular right or

7 For favorable takes on Hildebrand, see Schwarz 1960; and Hildebrand 2000. For a review of his early ethics, see Mertens 1969: 269-278. On the relation between personalism and resistance, see Seifert 1998.

8 For a brief account of Hildebrand's early philosophical mentors and friends, see Hildebrand 2012: 7-19.

9 See Wenisch 1994: 15-16. Like other realists, Hildebrand (1994: 15) observed "with great pain" Husserl's transcendental violation of reality.

10 Hildebrand 1916: 126-251. On Husserl's appreciation, see Schuhmann 1992.

11 The concept of Stellungnahme, as Hildebrand notes in Hildebrand 1916: 140 came from Reinach, though Husserl, too, anticipated it in his 1914 ethics lectures. Its most basic form was 'for' or 'against.' On the spontaneity of Stellungnahme, see Hildebrand 1916: 138.

12 On Wertantwort, see Seifert 1992: 34-58.

13 Hildebrand 1916: 154. On the Schelerian centrality of feeling, see Hildebrand 1922: 463-602. Hildebrand's student Balduin Schwarz (1949: 655-676), points out that all values, as per Scheler, stood in a hierarchy leading to the divine. 
wrong. The concept of states of affairs, introduced by Carl Stumpf and expanded by subsequent thinkers, provided an important correction to Brentano's objectivism, for ethics now involved not simply the proper judgment regarding an object's love-worthiness (as Brentano prominently maintained in The Origin of our Knowledge of Right and Wrong), but the complex situational relation between persons, objects, and values - a relationship of judgment and action aimed at realizing good. This conceptual expansion helped phenomenology better to confront real worldly circumstances. ${ }^{14}$

Additionally, Hildebrand shared Scheler's commitment to the whole spiritual person, not simply the mind, body, or ego. "Every experience," Hildebrand wrote, "is the experience of a person. (...) [and a] relation to the person always takes place whenever an experience is the bearer of moral value" (Hildebrand 1916: 214). Like other phenomenologists, the Protestant Hildebrand converted to Catholicism in 1914, adopting a faith that became the hub of his thought and fed his personalist vision. In a post-conversion essay on the recognition of value, Hildebrand fixed virtue in a person's "basic moral attitude [sittliche Grundhaltung]."15 Personal goodness, he averred, sprouted from a "single root (...) a spirit that is in all of us" (Hildebrand 1916: 587). He shared with other Schelerians a preoccupation with Christian virtues - and especially, like Kolnai after him, sexuality. ${ }^{16}$ Volumes on virginity and marriage appeared in 1927 and 1928, respectively, examining in worldly, embodied forms the interpersonal love that Scheler had exalted philosophically. ${ }^{17}$

Hildebrand's personalist convictions carried forward into 1930's Metaphysik der Gemeinschaft [The Metaphysics of Community], where he declared every affirmation of another person's worth "morally positive" and every rejection "negative." ${ }^{18}$ In a Schelerian critique that foreshadowed his own denunciation of Nazism, Hildebrand decried modern relativism and vitalism as value distortions and insisted that authentic community arose only from "devotion to God and one's neighbor." In the contemporary world, however,

man falls into the misconception that the ethos in which the individual feels simply a momentary part of the whole relieves one from the spasms of the I I Ichkrampf], lets one leave the egocentric position of the modern age. In this one forgets that

14 On the history of the Sachverhalt concept, see Baltzer-Jaray 2009: 41-66.

15 Hildebrand 1916: 548. Scheler, too, as is well-known, was a Catholic convert; Husserl converted from Judaism to Lutheranism.

${ }_{16}$ This personalist theme would later appear prominently in the work of the philosopher-turnedPope Karol Wojtyła.

17 Hildebrand 1962; 1984. Increasingly devout, he also published Liturgy and Personality: The Healing Power of Formal Prayer (Hildebrand 1960) in 1933, a book that defended Catholic liturgy as an essential element of worship.

18 Hildebrand 1955: 304. The analysis, of course, echoes Scheler's Formalism in Ethics. 
there is also a descent under one's own life, a descent into a merely vitalist 'social consciousness' whereby the individual relinquishes any spiritual attitude to which, as a personality, he is not only entitled but positively obliged. (Hildebrand 1955: 9)

Devotion to values and love of others, by contrast, allowed one to escape egotism and establish communal ties; indeed, personality grew from self-transcendence rather than self-possession. Values themselves had a socially unifying effect - a "virtus unitiva" - that helped to forge communities of purpose; this virtus was, in fact, "the key to understanding the objective structure of society" (Hildebrand 1955: 118). Communities came about, per Hildebrand, through a process of incorporation: the incorporation of values by persons, of persons into wider communities, and of persons and communities into the value realm. The "res publica"' - the true community - emerged in a shared openness to the value hierarchy and recognition of the "primacy of the individual person" (Hildebrand 1955: 185, 397). As a bridge to his anti-totalitarian activism, Hildebrand ended his 1930 tract with an attack on the "dangerous mistake" of state or social exemptions from morality, an apparent critique of both left and right moral relativism and German jurist Carl Schmitt's prominent theory of state exception. In 1933, he espoused instead a Christian corporatism that embedded persons in hierarchical 'natural' communities - family, church, nation, and only latterly, state. ${ }^{19}$ Within a year, he found a contemporary model of this vision in neighboring Austria.

With the Nazi ascension, Hildebrand, a vocal adversary since before the Beer Hall Putsch of 1923 - on a 1921 trip to Paris, he had condemned German nationalism and blamed his country for launching the Great War - made the difficult decision to leave his beloved Munich, passing first to his birth city of Florence and then on to Austria, where he championed Chancellor Engelbert Dollfuß' conservative Christian policies. ${ }^{20}$ Dollfuß has not fared well with historians: In the effort to overcome internal fragmentation and rising Nazi threats, he adjourned the Austrian parliament in March 1933 and imposed authoritarian rule - dubbed 'AustroFascist' by its critics - based on Christian corporatist principles. In line with recent papal doctrine, he sought to reorganize Austrian society into supra-partisan

19 Hildebrand 1933: 48-58. "The higher the domain of value," he continued, "the deeper the stratum in the person to which it beckons, and the more it addresses itself not only to the individual, but rather to the community" (Hildebrand 1933: 56) The passages are cited in James Chappel's (2012: 224) Slaying the Leviathan.

20 Hildebrand's resistance to German patriotism during World War I stood in marked contrast to the nationalism of Husserl, Scheler, Reinach, and other phenomenological contemporaries. On Hildebrand's battle against Nazism, see Ernst Wenisch's introduction to Memoiren und Aufsätze, as well as a concluding essay by Balduin Schwarz; and the essays collected in Seifert (ed.) 1998. On Hildebrand's remark about World War I, see Connelly 2012: 109. A longer discussion of Hildebrand and the Jew-turned-Catholic priest Johannes Österreicher is contained in Chapter 4 (Connelly 2012: 94-146). 
estates that would quell social disorder and promote loyalty to church and state. This effort prompted a strike in early 1934, which Dollfuß crushed in a bloody civil war that led to the abolition of the Social Democratic Party. The artillery bombardment of the Karl-Marx Hof, a low-income tenement block in Vienna's outskirts and a symbol of the city's progressive tradition, became an emblem of the chancellor's heavy-handedness. Claiming to defend Austria against Nazism, critics charge, he marched it halfway there.

Nonetheless, Dollfuß had his advocates. The essayist Karl Kraus came to respect his defiance of Hitler and defense of Austrian independence against Nazi calls for Anschluß And the newly-exiled Hildebrand not only viewed the chancellor's measures as necessary in the face of internal and external Nazi threats; he also saw them as midwives of a more devotional society that would reject the anomie of liberal modernity. In this regard, Dollfuß' authoritarianism did not contradict his vision of communal reciprocity; as James Chappel has shown, Hildebrand was one of the premier representatives of a conservative Catholic anti-Nazism that saw in hierarchical and illiberal corporatism a defense of the human person besieged by both right and left totalitarianism and liberal individualism (Chappel 2012: 200-246; 2011). Whereas both liberalism and totalitarianism stripped men of spiritual qualities and subsumed them in the amorphous mass, corporatism dignified each person by embedding him in communities of love and meaning, overseen and secured by the corporate state.

Upon arrival in Vienna, Hildebrand was recruited to edit the regime's mouthpiece journal Der christliche Ständestaat [The Christian Corporate State], funded by Dollfuß himself. ${ }^{21}$ In that capacity, he attracted around him "perhaps the central group of Catholic-conservative resistance against Nazism outside of Germany."22 In Dollfuß' vision of a corporate state organized around Christian communities and social estates, Hildebrand saw both a compelling alternative to totalitarian absolutism and a worthy response to the forlorn individualism and godlessness of liberalism. Indeed, modern antipersonalism, embodied in the rise of mass man and state leviathan, was liberalism's miscarried child - and it led, Hildebrand believed, directly to fascist nihilism. Austria's Catholic mission, he declared in 1933, was

to give the correct answer to the weighty mistakes of Liberalism, which have undermined Europe for centuries, to show the correct way for the German people in a time of boundless confusion, in which the bankruptcy of individualistic Liberalism has led to two new and far more terrible mistakes that threaten to destroy the

21 Rudolf Ebneth has written an excellent monograph on Hildebrand's Austrian journal, entitled Die österreichische Wochenschrift 'Der christliche Ständestaat': Deutsche Emigration in Österreich 1933-1938 (Ebneth 1976).

22 Seefried 2006: 251. Quoted in Chappel 2012: 205. 
whole of Western culture at its roots: Bolshevism and National Socialism. (Hildebrand 1994: 166)

In the face of existential threat, corporatism afforded the chance to rebuild organic communities around "solidary togetherness," to recognize that a person's responsibility to his ethos, family, church, and humanity preceded his duties as citizen and therefore needed state protection. ${ }^{23}$ Such a social and spiritual rehabilitation required the affirmation of man "as a being [Wesen] with an immortal soul and a calling to eternal community with God" - an integralist message that persisted throughout Hildebrand's Austrian years. ${ }^{24}$

While their focus was cultural and political, Hildebrand's essays in Der christliche Ständestaat rested on his phenomenological analyses of yesteryear. Most obviously, he defended the existence of a Christian-cum-Schelerian "hierarchy of goods" that National Socialists rejected in favor of "blood materialism." The Nazi "heresy" elevated the vital over the spiritual, degrading the person to a "mere function of blood and race" and denying the value-richness that phenomenology revealed (Hildebrand 1994: 168, 236-237). Nazism and Bolshevism, Hildebrand declared in 1941, now an American émigré, reflected an antipersonalist "slave uprising against the spirit," a tragic preemption of higher intellectual and spiritual values by the agents of blood and might (Hildebrand 1941: 457-472; 1994: 198). While this claim echoed Scheler's assault on modern ressentiment, Hildebrand also drew on another realist forebear, Reinach: the discovery of social acts presupposed the orientation of free persons to the independent world of values, a stance that Nazis and Bolsheviks - and Liberals before them - denied. ${ }^{25}$ Much of this critique was stock phenomenologicalese:

In today's chaos, in which the idolatry of the vital sphere has led to an antipersonalism and a revolt against the spirit, we must not see a corrective for rationalism, but a terrible aberration that simply draws its consequences from rationalism and makes for us the compelling task, now more than ever, to elaborate clearly the true nobility of the realm of the spirit and the spiritual person. (Hildebrand 1994: 185)

Like Husserl, Hildebrand blamed an overweening scientism for crippling human understanding and prompting a crisis of meaning and spirit. Only by acknowledging the infinite worth of persons and the objective hierarchy of values - realities

${ }^{23}$ Hildebrand 1994: 168, 191; 1954: 288. "The individual is not a citizen in the first instance," wrote Hildebrand in 1929. Quoted in Chappel 2011: 573.

24 Hildebrand 1994: 318. Man's highest aim, Hildebrand argued, was likeness to God and orientation toward the divine (Hildebrand 1994: 232).

25 Hildebrand 1994: 171. Hildebrand was fond of emphasizing, in phenomenological fashion, that his criticism concerned not simply the activities of Nazism, but its ideological essence. For Reinach's influential analysis of social acts, see Reinach 1983. 
disclosed by Scheler - could man hope to "rehabilitat[e] the spirit" (Hildebrand 1994: 205). This conviction fueled his forceful condemnation of Nazi racism in the 1937 talk "Jews and the Christian West," which rejected anti-Semitism on personalist grounds and celebrated Jews as a root of the Christian faith, a privileged people in God's eyes. ${ }^{26}$ Forced to flee Vienna a year later in the face of Nazi annexation, Hildebrand spent the second half of his life - a Christian philosopher at Fordham University - dedicated to the social and spiritual renewal he had adumbrated in his European years.

\section{Aurel Kolnai}

Hildebrand was not the only student of phenomenology to target Nazi dictatorship and European anti-Semitism. The list of contributors to Der christliche Ständestaat included several Jews-turned-Catholic with phenomenological backgrounds. Hildebrand called on Annie Kraus, an erstwhile Husserl student and a colleague of several interwar phenomenologists, to pen a 1934 critique of "religious antiSemitism." Kraus, who would not convert until 1942, insisted that Catholic appreciation for the Old Testament bound its believers to recognize Jewish contributions to their confession; the widespread Catholic anti-Semitism of the day was therefore a violation of the faith, even "an anti-Christianism." ${ }^{27}$ And Waldemar Gurian, who had studied with both Scheler and Hildebrand, pioneered what later became totalitarianism theory, linking Bolshevism and Nazism, putative enemies, under a unified term of opprobrium..$^{28}$ In neither of these cases, however, is there a clear connection between earlier phenomenological studies and later resistance writings, though the common background is suggestive.

For Hildebrand's fellow anti-Nazi Aurel Kolnai (1900-1973), by contrast, the link between phenomenology and activism was direct - or at least he aimed to make it so. Despite admiration for Hildebrand the philosopher, Kolnai differed vehemently from his elder colleague's views on Austria. The Hungarian Kolnai, whose experience under Bela Kun's Bolshevik Republic inspired a lifelong antipathy toward dictatorship, deemed his confederate's embrace of Dollfuß naïve and contemptible. "So great a philosopher, and no character, no backbone at all," he fulminated in $1934 .{ }^{29}$ Hildebrand's phenomenology was

directed against the pseudo-world of constructivisms, snobbisms, philosophies of ressentiment and of power-seeking spiritual supermen - intended to overcome the

26 Connelly 2012: 130-33; Hildebrand 1994: 340-358. Hildebrand himself had a Jewish grandmother.

27 Kraus 1934. On Kraus, see Connelly 2012: 113-115; and Rexin 2009.

28 On Gurian, see especially Chappel 2011; 2012.

29 Quoted in Dunlop 2002: 137. 
professional feeble-mindedness of thinking in formulae. (...) What a shame he is a toady of Austrofascism. (...) There is no philosophical thinker whose thought I am so close to (I've known that for years!) - and yet I shudder to shake hands with him when I think of his vomit-making Regime-salon Thursday evenings and his apotheosis of Dollfuß! ${ }^{30}$

Kolnai's revulsion at Hildebrand's political alliance illustrates in stark relief a fixation of his wider oeuvre: the failure of philosophers to translate ethical principles into effective moral practice.

Born to a liberal Jewish family, Kolnai fled Budapest for Vienna near the end of Kun's regime to avoid right-wing anti-Semitic reprisals. ${ }^{31}$ Working as an independent writer, he first took interest in phenomenology when he enrolled at the University of Vienna in 1922. ${ }^{32}$ Not only was the philosophy, he later wrote, a "glorious movement of a new realism, the most important departure in philosophy since Socrates and Aristotle;" in its Schelerian form, phenomenology spurred Kolnai's budding interest in Catholicism, a religion to which he would convert in 1926 (Kolnai 2002: 26). The phenomenological method, said Kolnai in his Hildebrand-influenced 1930 book on sexual ethics, offered "the most penetrating analysis" of spiritual and mental essence available to philosophers, revealing "what is really meant (...) in a spiritual act" and dispensing with scientific “inferences' and 'inductions" in order to "attain a 'direct view' of the objects or their spiritual structure." ${ }^{33}$ His conversions to phenomenology and Catholicism were clearly of a piece.

In later life, Kolnai was fond of saying that his 1925/26 dissertation on ethical value contained the seeds of all his subsequent thought. ${ }^{34}$ It is certainly true that the essay suggested the lines of his 1930s critique of Nazism. Its express purpose was to "complete the phenomenology of moral values" pioneered by Brentano, Husserl, Scheler, and Hildebrand by grafting onto it a Thomist affirmation of objective ends and moral rules in order to bind ideas with practical reality (Kolnai 2002: 4). Phenomenological ethicists, Kolnai averred, had left their task incomplete, confirming the existence of absolute values but failing to enlist them for moral practice. He would "design the bridges which lead to a morally valuable reality" (Kolnai 2002: 12). This engineering feat required him to span the chasms between absolute values, everyday circumstance, and contemporary norms, to

\footnotetext{
30 Quoted in Dunlop 2002: 146-147.

31 On Kolnai, see Dunlop 2002; Congdon 1991: 233-253; Balázs \& Dunlop 2004.

32 Kolnai 1999: 126. By his account, it was a course by the psychologist Karl Bühler that stimulated his interest in Husserl and Brentano. Kolnai 1999: 129.

33 Kolnai 2005: 2-3. Echoing Hildebrand and presaging Wojtyła, the book presented sexuality as central to a loving marriage, not simply a means of reproduction.

34 Kolnai 2002: xi-xiv. "Ethical Value and Reality" was published in 1927.
} 
"bring about an ethically desirable state of things ... on the basis of existent moral needs and powers" (Kolnai 2002: 3, 27).

The key to achieving this goal was recognizing that no single group of values should monopolize decision-making. The expanse of values was infinite and kaleidoscopic, and men needed a rubric to map it. To that end, Kolnai introduced the concepts of value limitation and gradation. Every value, he wrote, had "limits of appropriateness" and applicability, and at the margins it verged on domain of others (Kolnai 2002: 59). In addition, values were graded, each implying others that had a "watered down and (...) peripheral presence" in the precinct of the first (Kolnai 2002: 62). In other words, values interpenetrated, one or two emphatic in any given situation, others muted but present. As circumstances changed, new emphases arose.

Kolnai further specified four types of value experience. The most common ethical encounter was the struggle against vice - what Kolnai called value exclusion. So crucial was this police work that he dedicated much of his career to combating the evils of materialism and totalitarianism. But he also identified three further forms of value experience, these inclusive rather than exclusive: coordination, by which features of reality were related with compatible values; incorporation, through which one embraced and absorbed the values of a loved one; and directness, which indentured one to God and the good. The latter two in particular broached the heights of moral "rapture," through which a person transcended herself by affirming the being of another while still preserving the "distance" essential to personal dignity and autonomy (Kolnai 2002: 136-137).

Kolnai resisted the rigorist tendency to impose an austere moral yardstick on complicated human realities, a monomania typical of absolutism. Practical ethics, he insisted, had to abjure purity: responsible decisions required a survey of "the entire range of ethical value" appropriate to a situation (Kolnai 2002: 59). Duty ethics, vitalism, utilitarianism, and especially totalitarian planning - all of these attitudes disregarded the value conflicts intrinsic to moral life, yielding at times to "blatant immoralism" in the name of ethical absolutes. Communism in particular promoted a "moratorium on values" in its pursuit of false utopia, a bearing that betrayed deep "contempt for Mankind" (Kolnai 2002: 43, 105). Like Scheler and Hildebrand, Kolnai traced these ills to totalitarianism's liberal precursor - to the "atomistic individualism" that had laid waste to human community. As correctives in the quest for ethical renewal, he embraced Catholicism and democracy, the latter a "movement for social liberation and construction in the most serious and responsible sense" (Kolnai 2002: 157-158).

Like other Catholic phenomenologists, Kolnai saw the human person as an ultimate value. ${ }^{35}$ Accordingly, he preferred reform - what he celebrated as the

35 His descriptors were abundant: the person was "an axiological 'manifold," a "conjunction of experiences and acts $(\ldots)$ laid around an ethical core," responsible and willing "to take on obligations" (Kolnai 2012: 21, 147, 155). 
"[m]eliorism of the ethics of moral-mindedness" - over revolution because it respected the "precious value" of each person. ${ }^{36}$ Genuine reform, Kolnai insisted, required "the actual presence of ethical need, the availability of moral energy in the circles concerned, and respect for emphatic and consideration for unemphatic constants" (Kolnai 2002: 56). At times, reform could even entail drastic action: the revival of a materialist society, for example, demanded "extensive transformation" that involved "working, inventive, free and promising engagement for the cause of good in the business of the world" (Kolnai 2002: 158, 190). Yet it always respected real circumstances and genuine needs rather than sacrificing men to beautiful utopias.

Phenomenology, it seemed to Kolnai, provided the best philosophical prop for this ethical vision. Its appreciation of moral plenitude, its orientation toward objective values - what he called its value-intentionality - became the marks of ethical probity and good will (Kolnai 2002: 169-181).

The moral seriousness which most quickly leads us to intuit the idea of a finite concrete world is itself closely related to that reverence for the world which prevents us from inspecting and dissecting it as though it were a 'globe' we could roll about in the palms of our hands. (Kolnai 2002: 94)

By contrast, "[t]he pursuit of distant (...) ends" led revolutionaries to override present needs ${ }^{37}$ Men must resist "the dreary imperious demand to confine the motives of conduct within materially simple, indeed uniform bounds," an attitude driven by "ice-cold pride." Kolnai's own resistance to this form of politics increased in the 1930s.

Vienna's high press, with its sophisticated mix of cultural analysis and political commentary, was an ideal venue for Kolnai's philosophically-oriented social essays, and he was able, like Hildebrand, to adapt the technical and granular analyses of phenomenology to the more colloquial flair of local feuilletons. Throughout the late 1920s, in the face of Central Europe's polarizing politics, he penned a series of 'essential' analyses - presenting a phenomenon "according to its essence," not as a factual catalog of surface traits - of political and ideological movements on the radical fringes: the left and right extremists who threatened personal sanctity, distorted value hierarchies, and clamored for dictatorship. ${ }^{38}$

\footnotetext{
36 Kolnai, "Duty, Inclination, and 'Moral-Mindedness," (1928) in: Kolnai 2002: 191; Kolnai 2002: 156 .

37 Kolnai 2002: 34 . At the same time, more far-ranging ethical concerns and responsibilities could reveal "a calling of solitary dignity." (Kolnai 2002: 136-137, 144) There was simply no formula.

38 The quotation comes from Kolnai 1938: 19; but prominent earlier examples of the procedure include Kolnai 1926; 1927b. The best review of Kolnai's Vienna journalism is in Congdon 1991: 241-253. Despite his rejection of Hildebrand's politics, he did agree to contribute several articles
} 
Even as Kolnai joined the Social Democratic Party, however, his editorials displayed a deepening conservatism. Echoing phenomenological contemporaries such as Scheler and Hildebrand, Kolnai singled out Liberalism for particular censure. In two articles from 1927, he condemned Liberalism's utilitarian conception of progress; while they were right to emphasize the gradual amelioration of want over revolutionary fervor, Liberals reduced men to material contingencies, making them animalesque and poor. ${ }^{39}$ Rooted in naturalism, Liberal ideology denied the spirit and turned subjects into anonymous mass men who exemplified the scientific meaninglessness Husserl later diagnosed and incubated crises that extremists could exploit. ${ }^{40}$ As with Hildebrand, Kolnai linked the rise of Nazism to the depredations of Liberalism; in its "cult of 'relativism,' 'tolerance' and 'indifferentism, in its explanation of social phenomena by 'psychology', or by a succession of different 'modes of general outlook' or world attitudes of mind, the Liberal Spirit has definitely overreached itself" (Kolnai 1938: 15). In 1927, Kolnai declared Bolshevism a graver threat than Fascism because it was more seductive: as he put it colorfully, "it stood at once nearer to God and the devil" (Kolnai 1926: 213). By 1931, however, he was coming to see the Nazi threat as more urgent - a quintessential counter-revolution distinguished from conservative anti-Communism by its embrace of revolutionary violence, terror, and deception. ${ }^{41}$ In 1933's "Der Inhalt der Politik [The Content of Politics]," Kolnai assailed the right-wing jurist Carl Schmitt's vision of politics as an external relation of friend or foe. War, in Schmitt's view, was an intimate partner of the politics of existential survival. Kolnai countered by stressing the primacy of domestic political disputes and "the coexistence of opponents" in a common society. Political discussion, not mortal combat, was the "essential mark" of politics, its proper content debates over the "fashioning" of a shared destiny. ${ }^{42}$

In the face of Austria's increasing brutality, Kolnai continued to endorse the vision of a Europe of spiritual persons limned in his earlier phenomenological treatises. ${ }^{43}$ Indeed, we find in the 1930s his first clear statement of the pragmatic conservatism for which he became known in the West:

Conservatism, of the culture-, law-, person- and continuity-affirming sort, can only effectively take up its struggle against the anarcho-naturalistic extreme right

to Die christliche Ständestaat under the moniker 'Van Helsing,' cribbed from Bram Stoker's warrior against spiritual evil.

39 Kolnai, “Die Ideologie des sozialen Fortschritts," Der deutsche Volkswirt 1: 30(1927): 933-36; "Kritik des sozialen Fortschritts," Der deutsche Volkswirt 1: 31(1927): 965-69.

40 Kolnai seconded G.K. Chesterton's condemnation of the servile capitalist state in which property was plutocratically concentrated. Kolnai 1927a.

${ }^{41}$ Kolnai 1931/1932. On Nazism as counter-revolution, see Kolnai 1938: 672.

42 Kolnai, "What is Politics About?" in Balázs \& Dunlop 2004: 31, 34. Schmitt’s 1927 classic, revised and republished in 1932, is Schmitt 1996. For a recent summary of it, see Jay 2010: 86-89.

43 See e.g. Kolnai 1933/1934b: 444. 
if it is aware of being conservative with a very specific character and aims, which has distinct bridges to the left and takes over from it certain responsibilities, but otherwise occupies a middle point, from which it strikes the actual enemy, the right-totalitarian and mythical variety, beating it on its own territory and hitting it partly with its own weapons. (Kolnai 1924: 943)

Here he echoed the earlier call for a personalist order, Christian and democratic: Whereas "[f]ree democracy means the personalistic life of man in society, fascist dictatorship means the person-denying rule of the masses." ${ }^{4}$ No doubt it was for this reason that Kolnai deplored Hildebrand's truck with Dollfuß, for he saw in the Austrian strongman not a bastion against Hitler but an agent in the suppression of personal freedom and political liberty. ${ }^{45}$

In posthumously published memoirs, Kolnai reflected back on the relation between his phenomenological and political interests. While acknowledging the danger of abstraction from reality, he ventured that Husserl's brainchild had a democratic-conservative slant. "[I]t bases philosophy on the broad pediment of 'current experience' and develops it in keeping with the categories and valuations of ordinary man," Kolnai wrote. But this bias did not pander to base popular will or delirious visions of national unity:

The phenomenological attitude reveals... a 'democratic' slant in the sense of thinking 'in correspondence with' the thinking of the 'people,' not in the sense of any sanctification of 'the people's will.' It has a natural affinity to 'government with the people' rather than 'by the people.' It is aligned to the conservative-democratic idea of popular participation in government as opposed to the national-democratic and totalitarian formula of an 'identity between the rulers and the ruled.46

This democratic-conservatism, already emergent in the 1930s, became the hallmark of Kolnai's second career, after he fled Central Europe in 1937, settling ultimately in England where he was hailed by philosophers such as David Wiggins, Bernard Williams, and Pierre Manent. ${ }^{47}$ It drew expressly on phenomenological

44 Kolnai 1933-34a: 319; 1933/1934b: 442. Francesca Murphy identifies constitutional monarchy - at once conservative and democratic - as Kolnai's ideal. Introduction to Kolnai 1999: xi.

45 Kolnai also expressed guarded concern with the Catholic embrace of corporatism in the 1931 encyclical Quadragesimo Anno. See Kolnai 1931: 892.

${ }_{46}$ Kolnai 1999: 140-141. Kolnai's reverence for Tomáš Masaryk as "the greatest, noblest and truest representative of Western civilization" underscores his belief that democracy required guidance from wise leaders. See Kolnai 1938: 27, 223, 685. On Masaryk's vision of guided democracy, see Orzoff 2009: 8, 30-32. The War against the West reveals Kolnai's concern for 'titanism,' or the 'Superman' ideology - a Masarykian phrase designating modern humanity's hubristic tendency to elevate itself to the position of God. Kolnai 1938: 223.

47 Wiggins and Williams co-introduced a volume of Kolnai's later essays entitled Ethics, Value, and Reality (Kolnai 1978: ix-xxv). Pierre Manent admired Kolnai’s anti-utopian thought, most famously 
convictions little-known in the English-speaking world but shared by many of his Central European compatriots.

\section{Conclusion}

What should we take away from this survey of two lesser-known interwar philosophers regarding the social and political implications of phenomenology? First, it calls into question the common characterization of phenomenology as a brand of apolitical esoterica, a philosophy that only became worldly by partnering with other social and political traditions. As Hildebrand and Kolnai show, later East European phenomenologists such as Patočka, Wojtyła, or Józef Tischner did not have to graft onto phenomenology other overtly political programs in order to make it socially engaged; they could draw on a ready tradition of phenomenological social thought and engagement. Interwar first and second-generation phenomenologists were already tapping a novel repertoire of experiential analyses in order to make claims about ethical and social matters and even to bolster activism against totalitarian threats. Hildebrand and Kolnai exhibit one of the characteristic features of this phenomenological social thought in their insistence on embedding political claims in the bedrock of human experience - the real life of the person - and a world of objective moral values, putatively revealed by phenomenological insight.

It is perhaps tempting, given these examples of phenomenological anti-Nazism and anti-communism, to credit phenomenology primarily with exhibiting political will in times of grave crisis, when remaining apolitical was not a viable possibility. A philosophy that engages the social world only in times of extreme danger, we might concede, is hardly one with much utility in more mundane periods, when political evil is not quite so brazen. Not only, however, does this view ignore the range of stands taken by phenomenologists since the movement's origin; but more importantly it ignores one of the few red threads running through phenomenology's varied social and political manifestations: its critique of modern liberalism. Thus, Hildebrand and Kolnai - as well as Wojtyła and Patočka later on - saw totalitarianism not as a monster sui generis, but as a political emanation of the impoverished mental, moral, and communal world of modern liberal societies, with their atomized individuals, bureaucratic rationality, and market morality. In other words, phenomenological political thought was geared not only toward protecting men in times of terror but also toward building moral communities from the ground up in the modern industrial world. In this sense, it can speak to concerns

articulated in "The Utopian Mind," in Dunlop (ed.) 1995: 1-129. See Wiggins, "Aurel Kolnai and Utopia" and Manent "Aurel Kolnai: A Political Philosopher Confronts the Scourge of our Epoch," in Balázs \& Dunlop 2004: 219-230, 207-218. 
today about the price paid by the breakdown of community, the privatization of ethics, and the reduction of values to purely economic terms.

Finally, it is important to note the Catholic conservative slant of both Hildebrand's and Kolnai's positions, a widespread attitude among interwar phenomenologists, but a position that is unlikely to inspire much enthusiasm today. In Hildebrand's case, of course, it licensed the embrace of autocracy in the name of Christian corporate values. Indeed, despite his laudable attacks on Nazism and anti-Semitism, Hildebrand's position may again raise the spectre of phenomenology's 'bad politics'. It is important to recall, however, that despite Kolnai's claim that phenomenology had a 'conservative slant', it did in fact support non-conservative political positions at various points in its history. Here we should note the alliance of phenomenology and Marxist humanism across postwar Central and Eastern Europe, especially in 1960s Prague, Yugoslavia, and Hungary. ${ }^{48}$ It is thus inaccurate to characterize phenomenology as solely conservative in its political leanings. Its most steady social and political commitments - the critique of liberalism and the defense of the human person - could as well support left- as right-wing political critiques.

What this account does suggest is that phenomenological social and ethical theories have implications that extend beyond simply a proper understanding of an important school of philosophy. First, the tale of Hildebrand and Kolnai bears on our increased awareness of the political role played by interwar Catholicism in shaping the post-World War II world. As James Chappel, Piotr Kosicki, John Connelly and others have shown, the impact of Catholic thinkers on the postwar political settlement and the tempering of anti-Semitism in Western Europe was substantial indeed (Chappel 2012; Kosicki 2011; Connelly 2012). Phenomenologists provide an important chapter of this story. Furthermore, an account of early phenomenology allows us to place anti-communist regime critics of the 1960s and 1970s in their proper intellectual context rather than seeing them as liberal or market vanguards, a corrective with deep political implications as we continue to promote democratic and market reforms across the globe. Finally, the phenomenological understanding of the human being not simply as a calculating and self-interested individual but as a person with social and moral commitments, embedded in wider communities of meaning and purpose, provides a striking counterpoint to today's political and moral discourse, which seems unable to imagine sources of morality beyond the private individual or possibilities for collective social action. While phenomenological social thought need not be revived in its interwar forms, the recovery of phenomenological history can retrieve a valuable heritage with important lessons for how we arrived at the present political moment and valuable clues about what we should attend to in the future.

48 For a brief survey, see Satterwhite 1992. 
Bibliography

Balázs Z., Dunlop F., 2004, Exploring the World of Human Practice: Readings in and about the Philosophy of Aurel Kolnai, Budapest: Central European University.

Baltzer-Jaray K., 2009, Doorway to the World of Essences, Saarbrücken: VDM Verlag.

Brentano F., 1969, The Origin of Our Knowledge of Right and Wrong, London: Routledge

Brentano F., 1973, The Foundation and Construction of Ethics, London: Routledge.

Chappel J.G., 2011, The Catholic Origins of Totalitarianism Theory in Interwar Europe, Modern Intellectual History, vol. 8(3), pp. 561-590.

Chappel J.G., 2012, Slaying the Leviathan: Catholicism and the Rebirth of European Conservatism, 1920-1950, Ph.D. diss., New York: Columbia University.

Congdon L., 1991, Exile and Social Thought: Hungarian Intellectuals in Germany and Austria, 1919-1933, Princeton: Princeton University Press.

Connelly J., 2012, From Enemy to Brother: The Revolution in Catholic Teaching on the Jews, 1933-1965, Cambridge: Harvard.

Dunlop F., 2002, The Life and Thought of Aurel Kolnai, Aldershot: Ashgate.

Dunlop F. (ed.), 1995, The Utopian Mind and Other Papers, London: Athlone.

Ebneth R., 1976, Die österreichische Wochenschrift 'Der christliche Ständestaat': Deutsche Emigration in Österreich 1933-1938, Mainz: Matthias Grünewald Verlag.

Faye E., 2009, Heidegger: The Introduction of Nazism into Philosophy in Light of the Unpublished Seminars of 1933-1935, New Haven: Yale.

Findlay E.F., 2002, Caring for the Soul in a Postmodern Age: Politics and Phenomenology in the Thought of Jan Patočka, Albany: State University of New York Press.

Gordon P.F., 2010, http://ndpr.nd.edu/news/24316-heidegger-the-introduction-of-nazism-into-philosophy-in-light-of-the-unpublished-seminars-of-1933-1935/ (access: 1.12.2017).

Gubser M., 2014, The Far Reaches: Phenomenology, Ethics, and Social Renewal in Central Europe, Palo Alto: Stanford University Press.

Hart J., 1992, The Person and the Common Life: Studies in a Husserlian Social Ethics, Dordrecht: Kluwer.

Hildebrand von A., 2000, The Soul of a Lion: Dietrich von Hildebrand, San Francisc: Ignatius.

Hildebrand von A., 2012, Dietrich von Hildebrand's Acquaintance with Early Phenomenology, Quaestiones Disputatae - Selected Papers on Early Phenomenology: Munich and Göttingen, no. 3(1), pp. 7-19.

Hildebrand von D., 1916, Die Idee der sittlichen Handlung, Jahrbuch für Philosophie und phänomenologische Forschung, vol. 3, pp. 126-251.

Hildebrand von D., 1922, Sittlichkeit und ethische Werterkenntnis, Jahrbuch für Philosophie und phänomenologische Forschung, vol. 5, pp. 463-602.

Hildebrand von D., 1933, Die korporative Idee und die natürlichen Gemeinschaften, Der katholische Gedanke, no. 6, pp. 48-58.

Hildebrand von D., 1941, The World Crisis and Human Personality, Thought, vol. 16, pp. 457-72.

Hildebrand von D., 1950, Fundamental Moral Attitudes, Freeport, Books for Libraries.

Hildebrand von D., 1954, Die Menschheit am Scheideweg: Gesammelte Abhandlungen und Vorträge, K. Mertens (ed.), Regensburg: Verlag Josef Habbel. 
Hildebrand von D., 1955, Die Metaphysik der Gemeinschaft, Regensburg: Verlag Josef Habbel.

Hildebrand von D., 1960, Liturgy and Personality: The Healing Power of Formal Prayer, Manchester (NH): Sophia Institute.

Hildebrand von D., 1962, In Defense of Purity: An Analysis of the Catholic Ideals of Purity and Virginity, Baltimore: Helicon.

Hildebrand von D., 1984, Marriage: The Mystery of Faithful Love, Manchester (NH): Sophia Institute

Hildebrand von D., 1994, Memoiren und Aufsätze gegen den Nationalsozialismus, 1933 1938, Mainz: Matthias Grünewald Verlag.

Husserl E., 1973, Zur Phänomenologie der Intersubjektivität: Zweiter Teil: 1921-1928, The Hague: Nijhoff.

Husserl E., 1977, Cartesian Meditations, The Hague: Nijhoff.

Husserl E., 1987, Fichtes Menschheitsideal [in:] E. Husserl, Aufsätze und Vorträge, 19111921, Husserliana, vol. 25, Dordrecht: Kluwer, pp. 267-293.

Jay M., The Virtues of Mendacity: On Lying in Politics, Charlottesville: Virginia.

Judt T., 2011, Past Imperfect: French Intellectuals, 1944-1956, New York: NYU Press.

Kolnai A., 1926, Fascismus und Bolschewismus, Der deutsche Volkswirt, 1:7, pp. 206-213.

Kolnai A., 1927a, Der Abbau des Kapitalismus: Die Soziallehren G.K. Chestertons, Der deutsche Volkswirt 1: 44, pp. 1382-1386.

Kolnai A., 1927b, Rechts und Links in der Politik, Der deutsche Volkswirt, 23:2, pp. 665671.

Kolnai A., 1931, Quadragesimo Anno, Der österreichische Volkswirt, 23:2, p. 892.

Kolnai A., 1931/1932, Gegenrevolution, Pts. 1 and 2, Kölner Viertelsjahrshefte für Soziologie, 10:2/10:3, pp. 171-199, 295-319.

Kolnai A., 1933/1934a, Katholizismus und Demokratie, Der österreichische Volkswirt, 26:1, p. 319.

Kolnai A., 1933/1934b, Persönlichkeit und Massenherrschaft, Der österreichische Volkswirt, 26:1, pp. 442-444.

Kolnai A., 1934, Die Aufgabe des Konservatismus, Der österreichische Volkswirt, 26:2, pp. 943-946.

Kolnai A., 1938, The War against the West, New York: Viking.

Kolnai A., 1978, Ethics, Value, and Reality, Indianapolis: Hackett.

Kolnai A., 1999, Political Memoirs, Lanham: Lexington Books.

Kolnai A., 2002, Early Ethical Writings of Aurel Kolnai, transl. E. Dunlop, Aldershot: Ashgate.

Kolnai A., 2005, Sexual Ethics: The Meaning and Foundations of Sexual Morality, Aldershot: Ashgate.

Kosicki P., 2011, Between Catechism and Revolution: Poland, France, and the Story of Catholicism and Socialism in Europe, 1878-1958, Ph.D. diss., Princeton: Princeton University.

Kraus A.G., 1934, Der religiöse Antisemitismus im Lichte des Katholischen Dogmas, Der Christliche Ständestaat, no. 8, pp. 5-6.

Mertens K., 1969, Hinweise auf Dietrich v. Hildebrands Ethisches Werk [in:] D. von Hildebrand, Die Idee der sittlichen Handlung/Sittlichkeit und ethische Werterkenntnis, Darmstadt: Wissenschaftliche Buchgesellschaft, pp. 269-278. 
Orzoff A., 2009, Battle for the Castle: The Myth of Czechoslovakia in Europe, 1914-1948, New York: Oxford University Press.

Reinach A., 1983, The Apriori Foundations of Civil Law, Aletheia, vol. 3, pp. 1-142.

Rexin G., 2009, Kraus, Annie [in:] Biographisch-bibliographisches Kirchenlexicon, vol. 30,

Nordhausen: Bautz, pp. 810-814.

Satterwhite J.H., 1992, Varieties of Marxist Humanism: Philosophical Revision in Postwar Eastern Europe, Pittsburgh: University of Pittsburgh Press.

Scheler M., 1972, Ressentiment, New York: Schocken Books.

Scheler M., 1973, Formalism in Ethics and Non-Formal Ethics of Values, Evanston: Northwestern University Press

Scheler M., 1982, Der Genius des Krieges und der Deutsche Krieg [in:] M. Scheler, PolitischPädagogische Schriften, Gesammelte Werke IV, Bern: Francke, pp. 7-250.

Scheler M., 2008, The Nature of Sympathy, New Brunswick: Transaction.

Schmitt K., 1996, The Concept of the Political, Chicago: Chicago University Press.

Schuhmann K., Husserl und Hildebrand, Aletheia, vol. 5, pp. 6-33.

Schwarz B., 1949, Dietrich von Hildebrand on Value, Thought, no. 24, pp. 655-676.

Schwarz B.V. (ed.), 1960, The Human Person and the World of Values: A Tribute to Dietrich von Hildebrand by his Friends in Philosophy, New York: Fordham.

Seefried E., 2006, Reich und Stände: Ideen und Wirken des deutschen politischen Exils in Österreich 1933-1938, Düsseldorf: Droste.

Seifert J., 1992, Dietrich von Hildebrands Philosophische Entdeckung der 'Wertantwort' und die Grundlegung der Ethik, Aletheia, vol. 5, pp. 34-58.

Seifert J., 1998, Personalistische Philosophie und der Widerstand gegen Hitler [in:] J. Seifert (ed.), Dietrich von Hildebrand's Kampf gegen den Nationalsozialismus, Heidelberg: Universitätsverlag C. Winter, pp. 107-163.

Seifert J. (ed.), 1998, Dietrich von Hildebrand's Kampf gegen den Nationalsozialismus, Heidelberg: Universitätsverlag C. Winter.

Sokolowki R., 1999, Introduction to Phenomenology, Cambridge: Cambridge.

Szanto T. \& Moran D. (eds.), 2016, The Phenomenology of Sociality: Discovering the 'We', New York: Routledge.

Tucker A., 2000, The Philosophy and Politics of Czech Dissidence from Patočka to Havel, Pittsburgh: University of Pittsburgh Press.

Wenisch E., 1994, Einleitung [in] D. von Hildebrand, Memoiren und Aufsätze gegen den Nationalsozialismus, 1933-1938, Mainz: Matthias Grünewald Verlag.

Wolin R., 1992, The Heidegger Controversy: A Critical Reader, Cambridge: MIT. 